\title{
Special Theme 2: Asian and European Economic Integration at a Crossroads
}

\author{
Peter Claeys ${ }^{1}$, Helena Sanz-Morales ${ }^{1}$, and Camélia Turcu ${ }^{2+}$ \\ ${ }^{1}$ Vrije Universiteit Brussel, Belguim \\ ${ }^{2}$ University of Orléans, France
}

\section{Introduction}

This special issue contains a selection of four articles that were presented at the 21st INFER Annual Conference, jointly organized by the International Network For Economic Research $\left(\right.$ INFER) ${ }^{1)}$ and Vrije Universiteit Brussel (VUB) in June 2019 in Brussels, Belgium. The INFER Annual Conference has established itself as one of the leading economic conferences in Europe.

In Brussels, the conference was fortunate to have three distinguished keynote speakers: Jyrki Katainen (Vice-President of the European Commission), Hillel Rapoport (Paris School of Economics), and Barbara Rossi (Universitat Pompeu Fabra and Barcelona Graduate School of Economics).

The conference was not only successful in terms of the relevant keynote speakers but also in terms of the number of academics and researchers presenting their most recent contributions. Papers were presented in five parallel sessions with varying topics related to macroeconomics, regional economics, trade, migration and employment, e-commerce, equity markets, banking, gender, education, and energy economics. The conference also organized two panel discussions where attendants and speakers engaged in interesting debates and conversations. "The art of publishing in Economic journals" was of utmost interest for all the attendants at the conference as the panelists, who were editors of important economic journals, shared their tricks and tips

\footnotetext{
+Corresponding Author: Camélia Turcu

University of Orléans - LEO. Rue de Blois, 45067 Orléans Cedex 2, France. E-mail: camelia.turcu@univ-orleans.fr Acknowledgments: We wish to thank Professor Seongeun Kim, Editor of the Journal of Economic Integration, for giving us the opportunity to publish this special issue. Many thanks also to Yunhoe Kim, Managing Editor of the journal, for her excellent support. Our special thanks to the journal referees, the discussants, and the participants at the INFER Annual Conference 2019, for their insightful comments and suggestions. We are also grateful to our three keynote speakers and to all the colleagues and INFER board members who contributed to the excellent organization of the INFER Annual Conference 2019 .
} 
for successful publishing. "Jobs for economists" was especially useful for early career researchers as the panelists, working in very different institutional setups, shared their views on different career paths inside and outside academia.

\section{Asian and European Economic Integration: Background and Challenges}

This special issue is dedicated to the analysis of Asian and European integration. In Asia, the integration level among countries is not very high (Taghizadeh-Hesary et al., 2020) only exception is the Association of Southeast Asian Nations (ASEAN). Several initiatives have been considered within ASEAN to further strengthen economic integration to enhance, in the long run, the construction of an ASEAN currency area. Nevertheless, ASEAN is still a free trade area (which is the first stage of economic integration) while experiencing a certain similarity of exchange rate arrangements (Basnet et al., 2015). Therefore, a question that could arise would be: What are the macroeconomic and welfare benefits of a currency area compared to those of the independent managed floating if we consider the ASEAN countries? Europe is an excellent example of ever-closer economic integration between countries, reaching the stage of economic and monetary union in the Eurozone. Nevertheless, behind the overall picture, the European economic reality shows that the progress of European integration has not always been smooth (Bagnai \& Turcu, 2016); the deepening and enlargement have not always gone hand-in-hand and have not always impacted in a similar way all member states and their regions. Moreover, in the recent period, European integration has been marked by a slowdown, following the decision of the UK to exit (Brexit) the European Union (EU).

This special issue, meant to capture the challenges of European and Asian integration, was prepared through special times that are also closely linked, in one way or another, to the globalization process and market integration. Never before have we lived in a global dystopian experiment of this scale: during this Pandemic Crisis we are living in, we are keeping physically distant, have massively shifted our lives online, and are adopting similar health measures. Each country is developing policies to roll back the health and economic crisis that we are going through together.

Although the papers in this special issue do not specifically deal with the Pandemic Crisis, as they were submitted before the crisis started, they capture other global shocks that hit the Asian

1) INFER is a non-profit organization supporting science and research in all areas of economics. It currently has more than 250 active members and several institutional members across 37 countries on five continents, as well as a large pool of more than 1,000 occasional participants and supporters. INFER encourages scientific discussion during workshops on specific topics, hosts regular conferences, and offers numerous publication possibilities to its members. 
and the European continents, such as the Global Financial Crisis (GFC) or the Eurozone crisis.

Nevertheless, the Pandemic Crisis bears a remarkable similarity to the Great Financial Crisis that hit us just over a decade ago: a relatively small problem in one country (mortgages) quickly exposed the failures in the entire market of that country (US), consequently spreading to closely related markets (EU) and exposing particular weaknesses in the governance of global financial markets, with tremendous effects for domestic banks as well as public finances.

The degree to which financial trouble or a virus could quickly spread across markets shows how integrated economies and societies have become. In 2009-2010, we analyzed the channels by which US subprime mortgages could affect Greek bond yields. In 2020-2021, with the aim to analyze the channels by which a virus can spread through international air travel from a large city such as Wuhan to any remote island in the span of a few months.

Despite all the economic trouble, we have learned how to quickly move our lives online, which connected us globally on a scale that we had envisaged only for the future. The Internet has truly accelerated and connected our lives over the last two decades. It has become a major force behind cultural and personal integration across borders; it pushes economic changes without regard for institutional limits. Misgivings toward the societal changes driven by the Internet have been causing political upheaval in many countries, just as much as trade or financial integration has done.

The type of integration traditionally studied by economists mostly focuses on this top-down type of integration but overlooks the technological and societal drivers of integration that have grown bottom-up. This type of integration is a major force that goes beyond Europe and covers all countries. This close integration is accelerating everywhere and will continue to conflict with traditional institutions that are not fully equipped to tackle these challenges. Some of the papers in this issue correctly cover deeper economic integration in Asian countries and ask what type of institutions are adequate to tackle its challenges. Other papers look at how European banks have survived the Financial Crisis and how they can prepare for future challenges; or how countries or specific sectors have grown in recent times in Europe. The Pandemic Crisis shows that we urgently need tools to understand globally-connected phenomena to redesign policies to avert future crises.

\section{Studies Included in the Special Issue}

The case of the ASEAN countries is studied in the paper entitled "Exchange rate regimes in the ASEAN: Would a currency union outperform the independent managed floating regimes?" by Ibrahima SANGARE. The author underlines that over the last two decades, an increase in trade dependence between the ASEAN member states has been observed, together with a 
rise in intra-ASEAN foreign direct investment and specific changes in exchange rate arrangements and monetary policy frameworks of the ASEAN zone (in particular, Thailand, Indonesia, Malaysia, and Singapore, as underlined by IMF [2008]). Against this background, the feasibility of an optimum currency area in the region has been dealt with in the literature. Within this framework, the author takes a different view with respect to the existing literature and theoretically investigates (focusing on simulations on ASEAN countries) whether, when symmetric shocks occur, countries that join a currency union are better off compared to the situation where they keep their own independent managed floating regimes. A two open-country DSGE model is developed, which features nominal and real rigidities, incomplete pass-through of exchange rates, financial frictions, and a foreign currency denomination of private debt. In this setting, the author aims to study the effects of supply and demand shocks (in terms of macroeconomic and welfare outcomes) for countries under a currency union or under an independent managed floating regime. The model is further calibrated on the five founding members of the ASEAN (Thailand, Indonesia, Malaysia, Singapore, and the Philippines). In this setting, the author investigates the role of the coordination of independent policies. The results suggest that the macroeconomic and welfare performances of the ASEAN economies under independent managed floating regimes are comparable to those under a currency union. These findings are explained by the stability of the intra-regional nominal exchange rates arising from the similarity of policy rules under independent managed floating regimes. This implies that the choice of exchange rate targeting regimes with coordinated policies for the ASEAN countries that share similar trade patterns would be an appropriate solution to move toward a currency union. More precisely, when the ASEAN countries target their nominal effective exchange rates in a similar way (through coordinated policies) under independent managed floating regimes, they would evolve in a sort of de facto currency union that would provide the same benefits as a legally constructed currency union (de jure currency union).

During the past decades, the European construction and the banking institutions, in particular, have been exposed to new challenges. The EU moved to a single market phase in the $80 \mathrm{~s}$, to an economic union stage at the beginning of the $90 \mathrm{~s}$, and to a deeper monetary integration further on (i.e., in 1999, the single currency and the European Monetary Union were launched). The challenges imposed on the banking system (i.e., stronger liberalization, deregulation, technological changes, and internationalization) were particularly strong in the EU after the implementation of the Single Market Program and the introduction of the single currency. The latter has led to increased competition, particularly focusing on the efficiency of the banking system. Hence, EU banking institutions have needed to cope with the challenges of European integration as well as, more recently, with the consequences of the Global Financial Crisis and the Eurozone crisis. During the crises, some EU countries faced particular financial stress as well as imbalances in their public budgets. They had to request international financial assistance 
to survive the crises. Currently, the EU has overcome the crisis effects, but is experiencing new challenges related to the exit of one member-state, the UK (which is crucial for the EU financial and banking systems).

In this special issue, Brexit is analyzed from the perspective of financial integration and the banking system. This is done in the paper titled "Efficiency of the European banks in the aftermath of the financial crisis: A panel stochastic frontier approach" by Candida FERREIRA. The author investigates the banking efficiency across the $28 \mathrm{EU}$ countries ${ }^{2}$ ) for the period 2011-2017, using a Stochastic Frontier Analysis and panel estimates. The objective of the paper is twofold. On the one hand, it aims to analyze how efficient the EU banks are in the aftermath of the Global Financial Crisis. On the other hand, it investigates how EU banks might perform under the scenario that some key member-states (i.e., the UK, hence capturing Brexit) exit the EU or that the countries (Cyprus, Greece, Ireland, Portugal, and Spain) deeply affected by the GFC and the Eurozone crisis leave the EU. The results clearly indicate the presence of bank cost inefficiencies in the whole sample of 485 banks from all the $28 \mathrm{EU}$ member-states. They also suggest the existence of statistically significant technical inefficiencies in all considered scenarios of countries excluded from the sample. In particular, it seems that the exclusion of Italian and UK banks from the estimates would be more beneficial for the decrease of the banks' cost inefficiencies than the exclusion of French and German banks. Nevertheless, the exclusion of the from the EU countries that were deeply affected by the Eurozone crisis and the GFC and that have, therefore, restructured their banking systems would decrease the cost efficiency of the European banking system. Further investigations are needed in this setting, taking into consideration the long process of financial integration and the recent creation of the Banking Union.

The effects of financial integration and banking system development (i.e., associated with fast-growing financial and banking sectors) on growth and macroeconomic asymmetries might generate further questions related to risk-sharing and income smoothing in Europe (Beck et al., 2016; Kremer \& Popov, 2018). On these grounds, it would be interesting to analyze how income and sectoral convergence has evolved across European countries.

Eleonora CAVALLARO and Ilaria VILLANI examine in their paper titled "Club convergence in EU countries: A sectoral perspective" whether economic integration leads to increased similarity in the productive structures of countries and, furthermore, to convergence in sector-level productivity in the European Union. Their methodology is based on a non-linear factor model (Phillips \& Sul, 2009) that introduces transition dynamics and considers the potential heterogeneity of countries. In other words, the paper empirically assesses the convergence process at both the total economy and sector levels (e.g., six economic sectors are taken into account), considering potential heterogeneities between the $28 \mathrm{EU}$ countries 3 ). The results suggest not

2) The UK is considered in the analysis, as it was an EU member during the analyzed period.

3) The UK is considered in the analysis, as the time span analyzed in this paper is 1995-2015. 
only that EU countries have not converged - neither at the aggregate level nor at the sectoral level - but also that the differences among countries have increased since the recent GFC. They show that despite the successful integration of global production networks that stimulated the catching-up of most Central and Eastern European countries, asymmetries have increased following the recent global financial crisis. Additionally, heterogeneity between countries can be traced to differences in their vertical specialization, in the shares of innovation-intensive and high-skilled sectors; or they can be related to the factors determining the positioning of the countries in different income paths. Thus, this analysis can be relevant for the ongoing debate on the effects of the internationalization of production, shedding light on the growth prospects of countries while indicating some key policy implications.

Another sectoral study is further conducted in this special issue, but this time for a specific European country and a particular sector. In this setting, the study analyzes how sector characteristics including sustainability indicators affect consumer prices. More precisely, Katharina BISSINGER and Roland HERRMANN in their paper titled "Regional origin outperforms all other sustainability characteristics in consumer price premiums for honey: Empirical evidence for Germany" analyze the honey sector in Germany. This because the EU is the second-largest producer of honey worldwide as well as a key importer, while Germany has become a major producer of honey in recent years but also the largest honey importer in the EU. Against this background, the aim of the paper is to explain prices in this sector based on honey characteristics and to show the extent to which sustainability characteristics related to this particular sector yield a consumer price premium. The authors use a hedonic modeling approach that uses real market data and supply and demand factors that determine the implicit price and the marginal willingness to pay for product characteristics. It is worth underlying that they use recent data that is based on both online and offline prices. Moreover, they investigate whether the choice of a certain period affects the implicit prices of sustainability characteristics. Given the high price premium for regional honey, they also discuss whether sustainability concerns are the main reason for price markups. This is because sustainability and online retailing have become two of the main challenges in the food industry. A major finding of this study is that a clearly identified regional origin of the product outperforms all other sustainability characteristics (fair trade certification, organic production, or environmentally friendly packaging) in terms of the size of the consumer price premium. These results might suggest that food-safety concerns seem to be a key determinant of high consumer price premiums for defined origins. The latter seem to be more important for the high price premium than environmental issues or the willingness to support domestic honey producers. Thus, depending on their reputation, foreign suppliers might gain from international honey trade with Germany in different ways. These results can be extended into a more general framework to analyze whether there is a general pattern behind the consumer price premium of sustainability characteristics across different goods or sectors. 


\section{References}

Bagnai, A., \& Turcu, C. (2016). Recent monetary and financial developments in Europe. Comparative Economic Studies, 58(2), 147-151.

Basnet, H. C., Sharma, S. C., \& Vatsa, P. (2015). Monetary policy synchronization in the ASEAN-5: An exchange rate perspective. Applied Economics, 47(1), 100-112.

Beck, R., Dedola, L., Giovannini, A., \& Popov, A. (2016). Special feature A: Financial integration and risk sharing in a monetary union. Financial integration in Europe. European Central Bank, April.

Bissinger, K., \& Herrmann, R. (2021). Regional origin outperforms all other sustainability characteristics in consumer price premiums for honey: Empirical evidence for Germany. Journal of Economic Integration, 36(1), 162-184.

Cavallaro, E., \& Villani, I. (2021). Club convergence in EU countries: A sectoral perspective. Journal of Economic Integration, 36(1), 125-161.

Ferreira, C. (2021). Efficiency of the European banks in the aftermath of the financial crisis: A panel stochastic frontier approach. Journal of Economic Integration, 36(1), 103-124.

IMF. (2008). Annual report on exchange arrangements and exchange restrictions. Washington DC: IMF.

Kremer, M., \& Popov, A. (2018). Special feature A. Financial development, financial structure and growth: Evidence from Europe. Financial integration in Europe, European Central Bank, May.

Phillips, P. C. B., \& Sul, D. (2009). Econometric transition and growth. Journal of Applied Econometrics, 24(7), 1153-1185.

Sangaré, I. (2021). Exchange rate regimes in the ASEAN: Would a currency union outperform the independent managed floating regimes? Journal of Economic Integration, 36(1), 72-102.

Taghizadeh-Hesary, F., Yoshino, N., Chul Ju, K., \& Morgan, P. J. (2020). Regional economic integration in Asia: Challenges and recommended policies. Journal of Economic Integration, 35(1), 1-9. 